\title{
The Language of Albanian Renaissance Poetry: A Reflection of National Ideals
}

\section{Greta Jani}

\author{
Email: greta_jani@yahoo.com
}

\section{Doi:10.5901/ajis.2016.v5n3s1p314}

\begin{abstract}
The Albanian Renaissance is characterized by the development of a new ideology and culture under the influence of national enlightenment and democracy. The present paper aims to highlight the features of lexicon, style and word-formation in the poetry of the time. The paper focuses on the poetic works of two Albanian Renaissance writers: De Rada and Çajupi. Their poetic discourse gives evidence of a rich language full of expressive means and stylistic devices. The two poets, considered as pioneers of the laic poetry, concluded that because of the Turkish occupation the Albanian people did not have the opportunity to develop its own language and literature. According to De Rada and Çajupi the nation resurrection is connected with the resurrection of man, while its freedom with man's mind, spiritual enrichment and moral perfection. In this viewpoint, the lyrical perspectives of De Rada and Çajupi expressed in their poems intend to mirror a new world of human feelings, the aspirations of the poets for emancipation and their poetic individuality and unique personality. These motives brought to Albanian poetry an innovation and artistic richness that had not been known before. De Rada and Çajupi are the classical examples of the poets who expressed the spirit of the people through a simple and direct language which remains expressive and fresh despite the passing of time.
\end{abstract}

Keywords: language, lexical, stylistic, word-formation, poetry

The development of Albanian language was an important issue for the Albanian nation. "The sign of nationality is language, every nation exists because of it," said Sami Frashëri. When a nation loses its language, it loses its identity. Our nation not only survived in the course of centuries, but what is more important, all its national elements were conserved and transmitted through an unspoiled literary Albanian language. All this was achieved by the immense contribution of De Rada and Cajupi. Our nation takes pride in the attainment these poets. Thus we can mention them not only for their pure patriotic feelings, but also for their literary and linguistic accomplishments in their poems.

The Albanian Renaissance is characterized by the development of a new ideology and culture under the influence of nationality and democracy; by the attempts of the most prominent writers to protect and increase the usage of the Albanian language by opening Albanian language schools and contributing to the development of the Albanian Literature. The political, social and philosophical thought was influenced by the illuminists and the most prominent intellectuals of that time, but it was also highly inspired by the Albanian literature. The writers Pashko Vaso, Sami Frashëri, De Rada, Asdreni, Mjeda, Çajupi etc. dedicated all their literary creations to the national issue by using a rich lexis and unspoiled language. Furthermore they were very attentive to transmit their creativity and philosophical thought to the Albanian readers.

Trying to leave aside the intention to assess the literary developments of this period in prose and poetry, we have decided to highlight some features of the language of poetry, which transmitted not only the aspirations and the high patriotic ideals, but even the finest flickers of the spirit of the artistic literature authors of that time. We will focus on the poetic works of the Renaissance writers De Rada and Çajupi, even though the latter, more than the romantic tendencies, showed realistic tendencies in his poetic work.

The methodology implemented for the realization of this work is of a complex character, because a descriptive approach will be combined with the analyzing and synthesizing one. The rich linguistic material offered from De Rada's and Çajupi's poetic masterpieces "Këngët e Milosaos" ("Milosao's Songs"), "Skënderbeu i pafan", "Serafina Topia", "Baba Tomorri" ("Father Tomorri"), "14 vjeç dhëndër" ("14-year-old groom"), has been selected and studied with the intention to highlight some particulars of the language of Renaissance poetry. The examples extracted from these works will serve for the illustration of the theoretical issues.

Some centuries ago, De Rada commenced the fifth song of the poem "Këngët e Milosaos" ("Milosao's Songs") with the line of a great message: "Erdh dit' e Arbrit!" ("Arber's day has come"). Along with the concern transmitted for the fate of the country, the poet was the first to provide the Albanian language with a masterpiece with a real poetic value, through which he would show that he looked after this language, which had been neglected for several years, and tried to raise 
the Arbëresh dialect to the level of a standard language, even though this care damaged his work considerably, because time after time he suppressed the feeling and the inspiration, along with the simplicity and the spontaneity. Meanwhile, De Rada accepted that his style became difficult. ${ }^{1}$

"Këngët e Milosaos" one of the poet's most beautiful creations, is characterized with an internal equilibrium between the content and structure. ${ }^{2}$ Also, the lines of "Serafina", "Scanderbeg", through the rhythms which in some cases were impulsive and sometimes peaceful, touch us even today with the power of their feeling. With these masterpieces, De Rada was confirmed as a powerful and special voice in the Albanian literature of Renaissance.

The love for the home-country, the responsibility and the obligation to fight for the liberation of the country, the unification of the Albanian people leaving aside the conflicts and the disunion, are some of the major ideas of the time. A considerable obstacle in the way of politic unity was the religious disunion kept alive and encouraged by the ottoman conquerors and the chauvinist circles of the neighbouring countries. But "the Albanian is Albanian before he is a Muslim or an orthodox" - the poets accepted powerfully in their lines raising the idea of the nationality above the idea of religion.

In the patriotic lyrics of the volume "Baba Tomorri" ("Father Tomorri"), Çajupi would express exquisitely the love for the home-country, the persistent war of the Albanians to get liberated from the foreign suppression, through the hyperbole. For example: Treqind lebër qimeverdhë/Te Gryk'e Kuçit u derdhë; Trimërinë s'ia nxë dheu!; Po thërret sa tundet vendi etc.

Within the lyrics of this poet we will find even the ironic opinion towards the old-fashioned traditions, towards religion and God, when he constructs such questions which do not get an answer. For example: Pse u bë nga Perëndija?/Mirësia, ligësia/Që të vuaj njerëzia/Gjithë këto të këqia?

The lyrical poetry of Renaissance, particularly Çajupi's poetry brought to Albanian literature the spiritual world of the individual, the dramas of his life, a world in a turbulent movement, the spirit woken up from the medieval sleep which would numb the human mind. The sadness and the deep pain for the people, who would bear all the burden of the social injustice, is felt in every line of the poetry of that time. For example: Oh, të zestë punëtorë!/duke punuar qanin/se sa me kamçik në dorë/i qërtonin e i rrahnin. Dhe mos i godisnin pak!/bobo arapët e mjerë!/i rrahnin sa u del gjak/dhe sa vdisnin ca të tjerë.

An important feature of Renaissance culture and literature is the revitalization and reappreciation of the traditional values of the Albanian culture, particularly its close relation with the domestic folklore, the reemployment of the poetic motifs and forms of the oral popular productions.

The poetry of Renaissance was significantly influenced by the folk poetry. Çajupi's work mirrored the problems and the concerns of the people, its dreams and spirit, with a simple, understandable language for them ${ }^{3}$. The popular trend became a creative principle which is felt in all the works of the poet. The popular lexis and phraseology gave finesse, simplicity and sincerity to the expression of the feelings and to Çajupi's thoughts as well. The words and the expressions from the popular lexis, such as: sos, kuvendoj, qas, të piqemi, më të mëngjër, kandiset, fiqiri, qederi, sëra, ca petka vëravëra, të vdeç, të lëvdonjë, gjegja, etc. have gained poetic value in the lines of the poet, and demonstrate clearly his relation to the popular tradition. For example: Mike pse më prish fiqirë/përvëlon si zjarri?

The clarity, the simplicity of the phrase, the rich linguistic and stylistic figuration are special features found in the language of the people. These features involved in the respective language, according to Çajupi, had to be accepted through written works. Pursuing this way, Çajupi brought an invaluable contribution for the enrichment of Albanian language with the rich folk phraseology, with active and new phrases ${ }^{4}$. The idiomatic units provide the line with emotional nuances, and simultaneously reflect the poet's position. Some examples are: bëj këmbët bigë; këput qafën; lë shëndenë!; si buka që ha; heq shpirt; nuk kërren asnjë fjalë; fjalët i merr era; si dy e dy bëjnë katër; u pjell mendja; s'më dërsin veshi për botë; nga hunda s'më heq dot kurrë; u hante koka për brirë etj.

Apart from the influence from the folk poetry, De Rada was influenced even from the romantic poetry; therefore the lines at "Milosao", "Serafina" and "Scanderbeg" bear a wide figuration which is highly expressive. Such is the metaphor of the first lines of "Milosao": Bota kish ndërruar lisa/Uji i ri n'det kaltëronte n'ditn e re, etc. These lines transmit the idea of the revival of nature in spring, which implies the resurrection of man and of his poetic spirit. Furthermore, in this song, this

\footnotetext{
1 Shuteriqi, Dhimitër, 'Nëpër shekujt letrarë”, Në 150-vjetorin e lindjes së Jeronim De Radës (Through the literary centuries, On the 150th anniversary of Jeronim De Rada's Birthday), "Naim Frashëri”, Tirana, 1973, p. 158.

2 Kodra, Klara, "Studime për letërsinë shqiptare I" ("Studies on Albanian Literature"), De Rada's poems, Tirana, 1981, p. 196.

3 Xhaxhiu, Myzafer, "Shkrimtarë, vepra dhe dukuri letrare", A.Z.Çajupi-poet i shquar dhe mendimtar i Rilindjes sonë kombëtare, Tiranë, Shtypshkronja e Re, 1981, p. 28.

${ }^{4}$ Bulo, Jorgo, "Rreth ndikimit të folklorit në veprën e Çajupit", Studime Filologjike II, Tiranë 1966, p. 109.
} 
figure is used to express another state, the poet's concern for the fate of his own country which is threatened by the conquerors. This is how he expresses his ideas at song V of "Milosao": Përse të venë në det/ mendimet zemëra ime?/Zbardhuan anijëzat/Pranë këndej e u fshehën...

The poets expressed their prosperous spiritual world, the characters' nature or state through beautiful nominal or verbal metaphors, powerful stylistic means which made these works unrepeatable. Among the lines of "Milosao" and "Serafina" we find the metaphors: nata e zezë, zemrat u drodhën, fytyrat u errën, shiu i butë, mbiu një re manushaqesh, pranverë e bardhë, gjetkë mbytej mendja e saj, dielli i ra te shtrati, m'i këputi gjumin, m'u errësua jeta, flakë iu ndez fytyra trimit etc. Meanwhile at "Baba Tomorri" from Çajupi the following metaphors are distinguished: fluturon dashuria, ma paske gjuhën bilbil, zemra bëhet behar, zemëra jote u bë gur për mua etc.

The breathtaking Albanian nature, and particularly the countryside lifestyle with all its nature wonders, along with the problems and the concerns of the people who live there, will get the right position in the poetry productions of the authors of Renaissance. Çajupi is equally the sweet poet of the countryside as well as the poet of the city ${ }^{5}$. The opinions and the feelings of the poet will be compared in details from this wonderful nature. For example: shket si ngjalë, nusia si zog deti, faqekuqe si një shegë, koka më digjet si furrë, të ëmbël si shqerrë, zë si shpellë, paske trutë si hirrë, si një zog në kafaz, si burim i venë lotë, si sokadhe, si mollë e pabërë etc. This figure of speech is highly used even by De Rada. The poet constructs the figure of comparison with elements from the Albanian Arbëresh nature, which provide the lines with a special beauty and power of expression. For example: si ato lule qielli, si thëllëza te foleja, posi valë, si një flutur përmbi ujët, si suvala e detit, si drita në qiell e syu në kurm të fëmiut, porsi shqerrat në livadhe, si dallgë deti etc. Among the lines, the similitude or the extended comparison are also encountered very often. For example: Një hare më rodhi kurmit /si hareja kur te shtrati, mbrëmanet /vajza e ngrohtë ndien për të parëzën sisët që m’i fryhen; Duro zemër duro si duron mali me borë.

Çajupi treated even the love and social motives with e fine poetic sensation in some of the best poems of "Baba Tomorri". The beauty of the dear girl, the feelings of the lyrical hero, which are very concrete and human are often compared with the most beautiful elements of nature. These lyrics are nice and have communicative power even today. For example: Leshërat e tua posi pendë korbi/Ballëtë si diell, faqetë si mollë/Sisetë si shegë, dhëmbët si thëlpënjë/Buzët si burbuqe, sytë si gështenjë/Dora si dëborë, fjala jote mjaltë. The extended comparison which is spread in more than one line in Çajupi's poetry has sublimed this feeling which enriches the resurrected indivisual of this time. For example: $\mathrm{Si}$ dallëndyshja vete në vend tjetër/Dhe kthehetë prapë në fole të vjetër/Ashtu zemra jote mundet të kujtojë/Mikn'e djalërisë dhe prapë të dojë...

The social issues which were treated in the poetry of the period of Renaissance commence with the enslaved condition of the Albanian woman, to migration as a hurting wound of that time, to the detection of the contrast between the wealth and the poverty, etc 6 . In order to mirror the appropriately in his poetry, Çajupi uses in his poetry words of opposite meaning, antonyms. For example: zhvish-vish, lerë-vdesëm, pleqtë-të ritë, i zi-i bardhë, të pasur-të varfër, korrmbjell, dit'-nat' etc., which serve even for the construction of the antithesis and contrast providing his most powerful lyrical discourse. For example: Zhvish rrobat e robërisë mëmëdhe/Vish armët e trimërisë se ke ne!; Kemi lerë e do të vdesëm; Të rrojnë pleqtë/Të vdesin të ritë; Kasap i zi/ me zemër të bardhë; S’kish të pasur e të varfër; Kur të korr e kur të mbjell; Turpëronem dit' e nat'; Moj mike kush të gënjeul Dhe të shiti a të bleu?

Studying the language of the Renaissance poets it is noticed that they have a special feature, the feeling of the measure; in their lines ellipse is provided giving liveliness and grace. Çajupi writes: Malet me gurë,/fushat me bar shumë,/arat me grurë, më tutje një lumë.; Pika-pika bie shiu/dhe dëbora flokë-flokë,/vetëtin e fryn veriu,/breshëri kërcet mbi tokë; Mor zot, pse dëm fjalët? etj.

The phenomenon of ellipse is natural, or normal for the language, determined from different subjective or objective reasons. Therefore, it cannot always be related to the grade of self-awareness, because the language and the opinion realized in one subject have even an objective existence ${ }^{7}$. As the people say "to cut the long way short", even our poet leaves aside either consciously or unconsciously what can be implied. Therefore, we do not consider this as the poverty of the Çajupi's style, but as a phenomenon which is created due to an economic principle which everything not essential for the thought is left aside.

An elliptic form is even the structure $u$ encountered in the lines, the reduction of the full form of the personal

\footnotetext{
5 Bulo, Jorgo, "Andon Zako Çajupi", Studime Filologjike I, Tiranë 1991, p. 110.

${ }^{6}$ Haxhiaj, Floresha, "Andon Zako Çajupi Poezi”, Parathënie, "Naim Frashëri”, Tiranë, 1978, p. 9

${ }^{7}$ Prifti, Stefan, "Elipsa në sintaksën shqipe", Studime Filologjike III, Tiranë, 1966, p. 133.
} 
pronoun unë. For example: nga u ç'të ligë ke parë?; hëngra dhe u mish njeriu; or the incomplete form of the verb qan, of the nouns revole, telefon etc., for example.: ç'ke që qa prapë taninë?; nga një revol!; mund të na vijë një tel; or the reduction of the consonant $j$ such as in the examples: mbai për vete, vi rrotull etj.

The phonological reduction is a consequence of the linguistic economizing which is more spread in the conversational discourse and then it was taken even to the poetic language ${ }^{8}$. Due to the use of the ellipse several times, De Rada's language resulted to be difficult and not natural. Tommaseu explain that the ellipse, this syntax figure, is necessary in poetry. Even in De Rada's poems, its use has become a style-formation feature of the author. For example: Mendja tretur në ç'kish shkuar; Gjaku im te Lumi i Vodhit; Po tani të gjitha ëndrra!; Sa hie në ato zakone!

The beautiful and strong feeling of love provides the same force to the heroes to face the life-or-death wars and the poets have chosen the express it through the figures of the rhythms and sounds delicately. Here are some lines where the poetic explosions of Çajupi are expressed through the exclamation: O qipariz bujarësh! O $i$ bardhë bir bujari! 0 vasha kryegështenjë! Ditët e mia fatmira! The joy and the pain caused by love are expressed through direct intonation calls, which are caused due to the serious state where Albania is. In some other cases, the author expresses the concern about the youngsters who are leaving. For example: 0 moj Shqipëri e mjerë?; O pëllumb i shkruar!; 0 moj portë, moj e shkretë/Mos rri mbyllurë përjetë!; O kaur o këthatë!; O korrik, o faqezjarr!; O ju të ra dhe të ril; Obobo e ububu/Mikia ndër mënd u vu/Në shtëpi të saj më shpu...etj.

The exclamations are of different kinds: a) simple, 0 , $a$, oh, ah, etc; b) derivatives of simple words (with conversion from different parts of the speech): o burra, e zeza, lum, etc.

Very often, the inner world of the poet or the emotional and psychological states are emphasized through the figures which derive from the repetitions, such as anaphora, e.g.:. Bëre pemëtë me fletë/Bëre dimër e beharë/Bëre arinë dhe denë; Qani pyje, fusha, gurë/Qani male me dëborë! Me zë të madh si shkëmbi/Me zë të madh si gjëmimi etc. ; epanalepsis, e.g.:. Mbeta more shokë mbeta; Kurbeti shokë kurbeti; Duro, varfëri duro; U tretë, Gjon Lek', u tretë!; Bariu, shokë bariu etc.

The ideology of Renaissance was expressed through a synthetic poetic art where the poets wanted to give a lot through just a few elements, they wanted to make big figurative generalizations, etc. So it was a kind of art which mostly suggested rather than showed. For example: the concise style of De Rada did not accept the overloads and the exaggerations. It was distinguished for a normal figuration, without the exaggerated decorations and the fantasy. With an artistic intuition, simplicity and sincerity, he created beautiful epithets such as: valët kreshtërore, hadhia vilebardhë, vasha mespurtekë, re e ufme etj.

Furthermore, the irregular syntax assists the function of the idea in the lines written by the poets of this period. So in the lines the figure of inversion is very prominent. It emphasizes the qualities of the objects or the spiritual states of the characters in the poems of De Rada and Çajupi, such as: Rina, Milosao, Serafina, etc. In the lines of "Milosao", we find: e bardha shtëpia ime, me të lodhurat të bijat, të erëkëndshmen kafe pinte, një të hirshme zanë,të zbehtat faqe ia kam soditë, të hirshmet dhoma, të hajthmen dorë i putha, me një të trembur hare, me të nderëm bij bujarësh, me të bardhë cipë kreit, dheut huaj ahere ndër time motra kisha arritur etc.

The poetic lexics of Renaissance is rich even with composed words. It has been proved that composition in Albanian constitutes a very developed and folk type ${ }^{9}$. We find these features at De Rada in the function of an epithet. For example:

The formations noun + past participle:

gjifryrë, fatgëzuar, flokëthinjur, këmbëngjyer, ballukepërpushur, tehpërgjakur, kokëprerë, vështrimfyer, vështrimmekur, gjakmbytur, ballëvrejtur etc.;

The formations noun + noun:

syulli, mespurtekë,kryegështënjëzë,majëhekur, kryepluhurosurën, ëngjëllroja, hijezie, majëakull, qumështkrua, mendjemuzg, syflakë, flladpasosje etc.;

The formations noun + adjective:

ballëgjerë, flokëbardhë, buzëhieshmen, mendimqetë, shpirtbujar, ballëzbehtë, gojëhapët, pamjebardhë, orëbardhë, lëkurëshkretë, vilebardhë etc.;

The formations noun + adverb:

zakonbukur, drekëherë, nderplot, lotçurgë etc.

${ }^{8}$ Islamaj, Shefkije, "Gjuha dhe identiteti", TOENA, Tiranë, 2008, p. 257.

${ }^{9}$ Thomai, Jani, "Leksikologjia e gjuhës shqipe", TOENA, Tiranë, 2006, p. 182. 
Even at Çajupi, the compositions are folk formations with a high emotional nuance and with a high expressivity. For example: dorështrënguar, mustaqemath, meshollë, syzezë, gushëbardhë, kokëshinik, rrënjëdalë, mendjeprishur, zemërlig, zemërmirë, qimeverdhë etc.

Generally, Çajupi's compositions are formed from noun + adjective, such as: dorë+ e shtrënguar, mes+ $i$ hollë, sy+ e zezë, gushë+ e bardhë, zemër+ e ligë, punë+ e bardhë etc., where the second part determines the first. But there are even compositions which are formed from noun + noun, such as: kokë+ derr, kokë+shinik, zemër+ trim etc.

But even the formations through compositions were exploited by the poets to express the literary, artistic, esthetic ideas.

At De Rada, we can find formations:

With a prefix: pa-: e pafajme, i pakrypi, e pakujdesje, e pamëshirtë; për-: përbalti, të përhedhurat, përtrualli, përthan, përhodh, përshkit, përqafje, përthelluar, u përjoshën, përdorez; stër-: stërkrekosur,

With a suffix: -ake: fluturake; -ësi: mburrësi; -ëri: brishtëri; -ore: qiellore, kreshtërore, kallëzore, pengore, dritësore, gjelbërore; -lluan: zbardhëlluan; -llore: verdhëllore, bardhëllore; -ëz:vashëz, shenjëzën; -on:fushullon, hijeshon; -rimë: zhurmërimë; -ruar: e gjetheruar; -shëm: tronditshëm; -tar: djegtar, ndihmëtar, shëndetare, rrezetar, grënjëtar; -tore: zhurmëtore; -tur: lagështitur; -ëthin: zverkëthin, gërshetëthin; -th: qirith; -thi: djepthi, djalthi, ngatërrimthi; -uan: zbardhuan, zymtuan;

The adverbs were also used extensively in the lines of the authors of the period of Renaissance. They might be simple, with compositions, etc. the adverb with the suffix -(i)sht is identified in De Rada's language. For example: dhembshurisht, lirisht, krenarisht, zymtësisht, bindurisht etj. They are of different kinds: Way: mir(ë), bukur, lir(ë), rënd(ë), leht(ë), trash(ë), rrall(ë) etc.,; adverbs formed from the unification of a group of words ae.g.: përtrolli, menatë; the adverbs which are not found anywhere in the spoken discourses, in the written documents in Albanian, etc., with the suffix thi:qirithi; the adverbs formed from the repetition of the same word: vende-vende, copa-copa, besa-besë, rreshta-rreshta etc. Adverbs of quantity: pak, shum(ë), një cik(ë) etc.; Place: jasht(ë), këtej, këtu, atje, afër, përpara, prapa, kudo, posht(ë), matanë etc.; Time: sot, nesër, dje, parzën, mbrëmanet etc.

Poetry was the most elaborated and developed literary genre in the period of Renaissance. The poetic discourse of De Rada and Çajupi at that time give evidence of a rich language full of expressive means and stylistic figures. However, at De Rada there are some attempts to be consequent with the development and the improvement of the language in order to have a wide influence on the people.

Reading De Rada in the Arbëresh language, the people would get enriched spiritually and such characters such as Milosao, Serafina, Scanderbeg would serve as models of inspiration which would nourish their ethnical awareness, the love for the country, which was even the greatest mission of De Rada. This pioneer of the laic Albanian poetry of romanticism, reached the conclusion that under the hard conditions of Albania, which was conquered, the Albanian people did not have the opportunity to develop its own language and literature. So, it was the duty of the Arbëresh settlements in Italy to create a standard language and to transmit it to the home-country ${ }^{10}$. He was a man of Renaissance and the Albanian Renaissance would unify the political ideals of the citizens of the period of Renaissance and the human ideals of the resurrection of man. The nation resurrection and its freedom, in the thoughts of De Rada and Çajupi, is connected with the resurrection of man and his freedom, with his mind and spiritual enrichment, with his moral perfection. In this viewpoint, the lyrical perspectives of De Rada and Çajupi, expressed at "Këngët e Milosaos" and the poems of "Baba Tomorri" intend to mirror a new world of human feelings, the aspirations of the poets for emancipation and the acceptance of the individuality of their personality.

These motives were brought to the Albanian poetry the innovation and the artistic richness which had been not known before. De Rada and Çajupi remain the classical examples of the poets who expressed the spirit of the people through a simple and direct language, but which still remains expressive and fresh.

\section{References}

Bulo, Jorgo. (1991) "Andon Zako Çajupi", Studime Filologjike I, Tiranë.

Bulo, Jorgo. (1966) "Rreth ndikimit të folklorit në veprën e Çajupit", Studime Filologjike II, Tiranë.

Çajupi, Andon. (1902) "Pjesë të zgjedhura", Parathënie, Kairo.

Çajupi, Andon. (1957) Vepra, Tiranë.

10 Kostallari, Androkli, Studime Filolofjike III, Rreth një pikëpamje të Jeronim de Radës për formimin e gjuhës letrare të kombit shqiptar, Tiranë, 1981, p. 3. 
Haxhiaj, Floresha. (1978) "Andon Zako Çajupi Poezi", Parathënie, "Naim Frashëri", Tiranë.

Haxhiaj, Floresha. (1073) "Motivet sociale në krijimtarinë letrare të A.Z. Çajupit", Studime Filologjike II, Tiranë.

Islamaj, Shefkije. (2008) "Gjuha dhe identiteti", Tiranë.

Kastrati, Jup. (1956) Parathënie, "Poezi shqipe të shekullit XV", Kangë të Milosaut bir i sundimtarit të Shkodrës, Tiranë.

Kodra, Klara. (1981) "Poemat e De Radës", Studime për letërsinë shqiptare I, Tiranë.

Prifti, Stefan. (1966) "Elipsa në sintaksën shqipe", Studime Filologjike III, Tiranë.

Qosja, Rexhep. (1979) "Kulti i së shkuarës në letërsinë e Rilindjes", Studime filologjike I, Tiranë.

Resuli, Namik.(2007) "Shkrimtarët shqiptarë nga Buzuku te arbëreshët e Greqisë", "PAKTI".

Shuteriqi, Dhimitër. (1973) "Nëpër shekujt letrarë", Në 150-vjetorin e lindjes së Jeronim De Radës, Tiranë.

Shuteriqi, Dhimitër. (1974) Lavdia e De Radës, Gjurmime letrare, Tiranë.

Shapllo, Dalan. (1970) "Disa tipare të romantizmit në letërsinë shqipe të Rilindjes Kombëtare", Studime filologjike IV, Tiranë.

Thomai, Jani. (2006) "Leksikologjia e gjuhës shqipe",Tiranë.

Xhaxhiu, Myzafer. (1981) A.Z.Çajupi-poet i shquar dhe mendimtar i Rilindjes sonë kombëtare, Shkrimtarë, vepra dhe dukuri letrare, Tiranë. 